\title{
Cucumber Possesses a Single Terminal Alternative Oxidase Gene That is Upregulated by Cold Stress and in the Mosaic (MSC) Mitochondrial Mutants
}

\author{
Tomasz L. Mróz ${ }^{1}$ Michael J. Havey ${ }^{2} \cdot$ Grzegorz Bartoszewski $^{1}$
}

Published online: 21 April 2015

(C) The Author(s) 2015. This article is published with open access at Springerlink.com

\begin{abstract}
Alternative oxidase (AOX) is a mitochondrial terminal oxidase which is responsible for an alternative route of electron transport in the respiratory chain. This nuclearencoded enzyme is involved in a major path of survival under adverse conditions by transfer of electrons from ubiquinol instead of the main cytochrome pathway. AOX protects against unexpected inhibition of the cytochrome $\mathrm{c}$ oxidase pathway and plays an important role in stress tolerance. Two AOX subfamilies (AOX1 and AOX2) exist in higher plants and are usually encoded by small gene families. In this study, genome-wide searches and cloning were completed to identify and characterize AOX genes in cucumber (Cucumis sativus L.). Our results revealed that cucumber possesses no AOX1 gene(s) and only a single AOX2 gene located on chromosome 4. Expression studies showed that AOX2 in wild-type cucumber is constitutively expressed at low levels and is upregulated by cold stress. AOX2 transcripts and protein were detected in leaves and flowers of wild-type plants, with higher levels in the three independently derived mosaic (MSC) mitochondrial mutants. Because cucumber possesses a single AOX gene and its expression increases under cold stress and in the MSC
\end{abstract}

Electronic supplementary material The online version of this article (doi:10.1007/s11105-015-0883-9) contains supplementary material, which is available to authorized users.

Grzegorz Bartoszewski

grzegorz_bartoszewski@sggw.pl

1 Department of Plant Genetics, Breeding and Biotechnology, Faculty of Horticulture, Biotechnology and Landscape Architecture, Warsaw University of Life Sciences, ul. Nowoursynowska 159, 02776 Warsaw, Poland

2 Agricultural Research Service, U.S. Department of Agriculture, Vegetable Crops Unit, Department of Horticulture, University of Wisconsin, 1575 Linden Dr., Madison, WI 53706, USA mutants, this plant is a unique and intriguing model to study AOX expression and regulation particularly in the context of mitochondria-to-nucleus retrograde signaling.

Keywords Alternative oxidase · Cucumis sativus · Gene structure $\cdot$ Mitochondrial mutants

\section{Introduction}

Alternative oxidase (AOX) is a nuclear-encoded ubiquinoloxygen oxidoreductase associated with an alternative mitochondrial pathway that reduces the potential of reactive oxygen species (ROS) produced during respiratory electron transport (Elthon and McIntosh 1987; Vanlerberghe and McIntosh 1997; Maxwell et al. 1999). AOX is located on the matrix face of the inner mitochondrial membrane with binuclear iron atoms at the catalytic site (Siedow et al. 1995; Andersson and Nordlund 1999). The first AOX gene was cloned and characterized in the thermogenic plant Sauromatum guttatum (Schott) (Rhoads and McIntosh 1991). Later, AOX genes were described in some non-thermogenic plants (McDonald 2008). In higher plants, AOX is encoded by small gene families (three to five members), for example five genes in Arabidopsis (Arabidopsis thaliana) (Saisho et al. 1997; Clifton et al. 2005), four in tomato (Solanum lycopersicum) (Borecký et al. 2006), and three in maize (Zea mays) (Karpova et al. 2002) and soybean (Glycine max) (Whelan et al. 1996). Two AOX subfamilies (AOX1 and AOX2) can be distinguished by their sequences (Considine et al. 2002). Expansion and functional diversification of AOX1 genes have been observed in both monocots and eudicots, while the AOX2 subfamily so far has been found only in eudicots (Considine et al. 2002; Costa et al. 2014). In the Fabales, AOX2 gene duplications have been described (Cavalcanti 
et al. 2013; Costa et al. 2014). Recently, a detailed classification of AOX families based on protein sequences was proposed, which divides the AOX2 subfamily into two types: constitutively expressed AOX2a-c and stress-responsive AOX2d (Cavalcanti et al. 2013; Costa et al. 2014).

Each member of the AOX gene family has specific tissue and developmental stage expression patterns (Saisho et al. 1997). AOX1 genes are upregulated by ROS, salicylic acid (SA), and stresses (cold, drought, salinity, pathogens) (Considine et al. 2002; Clifton et al. 2005; Borecký et al. 2006; Feng et al. 2010; Zhang et al. 2012). Increased AOX expression lowers mitochondrial ROS production from an impaired respiratory chain (Maxwell et al. 1999). ROS also act as signaling molecules affecting retrograde (chloroplast or mitochondrial to nucleus) signaling (Apel and Hirt 2004; Woodson and Chory 2008; Leister 2012). In higher plants, one of the most common responses to the mitochondria-to-nucleus signaling is related to increased AOX level (Zarkovic et al. 2005; Rhoads and Subbaiah 2007). AOX is likely responsive to multiple and complex signals of respiratory status that are controlling nuclear gene expression including AOX gene (De Clercq et al. 2013; Vanlerberghe 2013). Recent studies indicate that NAC domain-containing protein 17 (ANAC017) is one of the direct positive regulators of Aoxla in Arabidopsis and contributes to the retrograde signaling network ( $\mathrm{Ng}$ et al. 2013). Therefore, AOX is increasingly being studied in the context of retrograde regulation between the nucleus and mitochondria (Giraud et al. 2009; Ivanowa et al. 2014; Ng et al. 2014), as well as in the acclimation of plants to biotic and abiotic stresses (Giraud et al. 2008; McDonald 2008; Cvetkovska and Vanlerberghe 2013). Robson and Vanlerberghe (2002) reported that lack of AOX in transgenic tobacco cells dramatically influenced programmed cell death (PCD). Moreover, overexpression of AOX resulted in smaller hypersensitive response lesions, suggesting that AOX may act as a suppressor of PCD in virus-infected leaves (Ordog et al. 2002). Plant mitochondrial mutants or nuclear mutants which affect mitochondrial function show mutant-specific expression patterns of AOX genes (Karpova et al. 2002; Sosso et al. 2012).

Cucumber is a unique model plant to study organellar genetics (Havey et al. 2002; Bartoszewski et al. 2007). It is characterized by differential transmission of the three plant genomes (paternal for mitochondrial, maternal for plastids, and bi-parental for nuclear) (Havey 1997; Havey et al. 1998); relatively large mitochondrial DNA (mtDNA) in which inter- and intramolecular recombination results in mtDNA rearrangements (Lilly et al. 2001; Bartoszewski et al. 2004; Alverson et al. 2011); and availability of cell cultures developed mosaic (MSC) mitochondrial mutants possessing unique rearrangements within their mtDNA (Malepszy et al. 1996; Bartoszewski et al. 2007). Several MSC lines with distinct phenotypes have been derived independently in cell cultures from the highly inbred line B and it has been proposed that the passage through cell cultures may be used as a way to produce cucumber mitochondrial mutants (Ładyżyński et al. 2002; Bartoszewski et al. 2007). The most extensively studied MSC16 mutant has a large $15.1 \mathrm{~kb}$ deletion of a non-coding region (JLV5) and duplication of the RPL5 region in its mtDNA (Lilly et al. 2001; Bartoszewski et al. 2004), negatively affecting respiratory complex I and increasing ROS production (Juszczuk et al. 2007; Szal et al. 2009).

The aim of this study was genome-wide identification, cloning, and expression profiling of AOX genes in cucumber. Recently, Costa et al. (2014) suggested that Cucurbitales possesses only one AOX2. We provide direct experimental evidence that cucumber possesses no AOX1 gene(s) and only a single AOX2 gene on chromosome 4 encoding an AOX2a-c type of protein. Additionally, we show that cucumber AOX2 is transcriptionally upregulated in different MSC mutants and by cold treatment. Expression studies suggest a distinct role and complex adjustment of the cucumber AOX2 gene making cucumber, for which lines with different mtDNA rearrangements are available, a unique and intriguing plant model to investigate the regulation of the AOX expression and mitochondrial retrograde signaling.

\section{Materials and Methods}

\section{Plant Material}

Origins and seed sources of highly inbred line B, which in this study represents wild-type (interchangeably hereinafter referred to as the control line), and MSC mitochondrial mutant lines 3, 12, and 16 (each independently derived from line B) have been described (Malepszy et al. 1996; Bartoszewski et al. 2007).

\section{Tissue Collection from Field Grown Plants}

Cucumber plants were grown in the experimental field of the Department of Horticulture, University of Wisconsin (Madison, WI, USA) during summer growth season under standard open-field cultivation procedure. Cucumber transplants were prepared in the greenhouse and planted at the end of May to the field. Leaves and male flowers were collected in the second part of June from 6- to 8-week-old plants (11-15 leaves), pooled $(n=12)$, and immediately deep-frozen in liquid nitrogen. The tissue was used in Northern and Western blot analysis.

\section{Plant Experiments Under Controlled Conditions}

Seeds were surface-sterilized in a $10 \%(v / v)$ solution of commercial bleach $(0.45 \%$ sodium hypochlorite final 
concentration) for $5 \mathrm{~min}$, washed three times in distilled water, and allowed to imbibe in distilled water for $24 \mathrm{~h}$ at $28^{\circ} \mathrm{C}$. Imbibed seeds were sown into the commercial soil mixture Humovit brand (Hit-Torf, Łomża, Poland) and grown in CMP6050 phytotron (Conviron Winnipeg, Canada). The plants were grown at $25^{\circ} \mathrm{C}$ during the day and $20{ }^{\circ} \mathrm{C}$ during the night and a 16-h photoperiod under fluorescent white light: $400 \mu \mathrm{mol} \mathrm{m}^{-2} \mathrm{~s}^{-1}$ and a relative humidity of $55-65 \%$. MSC mutants are characterized by slower growth (Malepszy et al. 1996; Bartoszewski et al. 2007); therefore, to compensate the physiological growth phases, MSC12 and MSC16 lines were sown 2 days earlier than the control line. Plant tissues were collected when the cucumber plants possessed a fully expanded first true leaf (about 12-14 days after sowing).

For cold treatment, cucumber plants possessing fully expanded first true leaf were chilled at $4{ }^{\circ} \mathrm{C}$ for $8 \mathrm{~h}$ under fluorescent white light $400 \mu \mathrm{mol} \mathrm{m}{ }^{-2} \mathrm{~s}^{-1}$ (Kozik and Werner 2008). After cold treatment, the plants were placed back under the same temperature and light conditions as before chilling and were further cultivated. Plant tissues were collected before chilling, $1 \mathrm{~h}, 48 \mathrm{~h}$ ( 2 days), and $144 \mathrm{~h}$ ( 6 days) after chilling. In all experiments, tissue was collected by cutting the plants $0.5 \mathrm{~cm}$ below the cotyledons. Collected tissues for each line and experimental conditions were pooled $(n=5)$, immediately frozen in liquid nitrogen, ground using mortar and pestle, transferred to $1.5-\mathrm{ml}$ tubes, and used for RNA or protein isolation and RT-qPCR and Western blot analyses.

\section{Cloning of AOX2 Gene from Cucumber}

Genomic DNA from MSC16 was subjected to PCR to amplify AOX gene(s) using the degenerated oligonucleotides P1 and P2 (Table 1) designed for conservative regions of AOX proteins as described by Saisho et al. (1997). A single $446 \mathrm{bp}$ fragment was amplified and cloned after TA tailing. DNA of 15 putative cucumber AOX clones were sequenced using Sanger method at the IBB Sequencing and Oligo Synthesis Core (IBB Oligo, Warsaw, Poland) to confirm their identities. Using genome walking, a larger (3,474 bp) AOX clone was isolated from vectorette libraries generated by digesting genomic DNA from MSC16 with one of five restriction enzymes (BamHI, EcoRI, HindIII, HaeIII, and EcoRV) followed by ligations with adapters compatible with these enzymes as described by the manufacturer (Sigma-Aldrich, St. Louis, MO, USA). The libraries were subjected to PCR using the vectorette-adapter-specific primers and cucumber AOX specific primers (OXF1 and OXR1, Table 1), according to the manufacturer's protocol. The PCR reactions were diluted 1:100 and used as a template for an additional PCR using nested vectorette-specific and cucumber AOX-specific primers (OXF2 and OXR2, Table 1). Amplicons were cloned by TA tailing and Sanger sequenced (Genomed S.A., Warsaw, Poland). Further genome walking was completed using the vectorette libraries as described above and AOX-specific primers (Table 1).

\section{3' and 5' Rapid Amplification of cDNA Ends (RACE)}

$3^{\prime}$ and $5^{\prime}$ RACE was used to clone the full length of AOX2 cDNA from cucumber. Total RNA was isolated from MSC16 leaves and treated with DNaseI (Promega, Madison, WI, USA). 3' and 5' RACE was performed using GeneRacer RLM-RACE kit according to the manufacturer's protocol (Invitrogen, Carlsbad, CA, USA). Primers specific for the alternative oxidase cDNA sequence were used for primary PCR - primer AOX389 39 for 3' RACE and primer AOX204 for 5' RACE, and for nested PCR primer AOX822 for $3^{\prime}$ end and AOX92 for $5^{\prime}$ RACE (Table 1). Full length AOX cDNA was PCR amplified from the total RNA to confirm the results. Sequence data from all clones were edited and contigs were aligned with Sequencer 5.1 (Gene Codes, Ann Arbor, MI, USA).

\section{Southern and Northern Blot Hybridization}

Single 446 bp AOX clone was nick-translated and hybridized to DNA-gel blots of the cucumber line B, the melon (Cucumis melo L.) cultivar 'Iroquois', the watermelon (Citrullus lanatus [Thomb.] Mansf.) cultivar 'Dixielee', Cucurbita pepo L. 'Dark Green Zucchini', and Cucurbita moschata Duch. 'Butternut'. In preliminary experiment DNAs of cucumber, melon, watermelon, and Cucurbitas were digested with three enzymes (EcoRI, HindIII, and $X b a \mathrm{I})$. Additionally, cucumber line B DNA was digested with nine enzymes (BamHI, BgIII, DraI, EcoRI, EcoRV, HaeIII, HindIII, SacI, and XbaI). The nick-translated 446 bp AOX clone was also hybridized to RNA-gel blots prepared from total RNA isolated from leaves and flowers from line B (wild-type) and MSC16. Both hybridization analyses were performed as previously described by Bartoszewski et al. (2004).

\section{Cucumber Fosmid Library Screening}

The cucumber fosmid library described by Meyer et al. (2008) was screened by filter hybridization. A single clone with 446 bp AOX fragment was hybridized with the library as described earlier. DNA of AOX-carrying fosmid was isolated by Qiagen Plasmid Maxi Kit (Qiagen, Hilden, Germany) and sequenced using 454 technology at the IBB PAN Sequencing and Oligo Synthesis Core (IBB Oligo, Warsaw, Poland).

\section{The Representative Set of AOX Proteins}

A set of 42 sequences of AOX proteins was selected from NCBI GenBank and used in phylogenetic analyses, accession numbers: Arabidopsis thaliana AOX1a (NP_188876), AOX1b 
Table 1 Oligonucleotide primer pairs used in this study to amplify and clone alternative oxidase (AOX) genes from cucumber and in RT-qPCR analysis

\begin{tabular}{|c|c|c|c|}
\hline Primer & Sequence $\left(5^{\prime}\right.$ to $\left.3^{\prime}\right)$ & Description & Reference \\
\hline $\begin{array}{l}\text { P1 } \\
\text { P2 }\end{array}$ & $\begin{array}{l}\text { CTGTAGCAGCAGTVCCTGGVATGGT }^{\mathrm{a}} \\
\text { GGTTTACATCRCGRTGRTGWGCCTC }^{\mathrm{a}}\end{array}$ & Degenerated primers & $\begin{array}{l}\text { Saisho } \\
\quad \text { et al. (1997) }\end{array}$ \\
\hline $\begin{array}{l}\text { OXF1 } \\
\text { OXR1 }\end{array}$ & $\begin{array}{l}\text { CTTCTTCAAGCAGGGCCTTAATCC } \\
\text { CTGCTCCCGCCATTGCCATCGACT }\end{array}$ & $\begin{array}{l}\text { Vectorette primary } \\
\text { primers }\end{array}$ & This study \\
\hline $\begin{array}{l}\text { OXF2 } \\
\text { OXR2 }\end{array}$ & $\begin{array}{l}\text { TGCTGAAACTTCCTCAGAGACTTC } \\
\text { GGATGCAAGGCTGAAGGATGTTAT }\end{array}$ & $\begin{array}{l}\text { Vectorette nested } \\
\text { primers }\end{array}$ & \\
\hline $\begin{array}{l}\text { AOX204 } \\
\text { AOX92 }\end{array}$ & $\begin{array}{l}\text { TCCACTGGAATCCACCATCCGACA } \\
\text { CAGGCAAACTTAAAAGAACATCGAGCTA }\end{array}$ & $\begin{array}{l}\text { 5' RACE } A O X 2 \\
\text { primers }\end{array}$ & \\
\hline $\begin{array}{l}\text { AOX389_39 } \\
\text { AOX822 }\end{array}$ & $\begin{array}{l}\text { ATGAATCGGATTGTGATTAGGAGTCTT } \\
\text { TGGCTATTTGGAAGAGGAAGCGATCCA }\end{array}$ & $\begin{array}{l}3^{\prime} \text { RACE } A O X 2 \\
\text { primers }\end{array}$ & \\
\hline $\begin{array}{l}\text { CsAox2FL_F } \\
\text { CsAox } 2 \mathrm{R} 101\end{array}$ & $\begin{array}{l}\text { AATACGAGGGTAATTCACATCAACCAA } \\
\text { TATGAAGCAAACCCCTGAGAAGAC }\end{array}$ & $\begin{array}{l}\text { RT-qPCR primers } \\
\text { Product size } 126 \mathrm{bp}\end{array}$ & \\
\hline $\begin{array}{l}\text { CsAox } 2 \mathrm{~F} 1155 \\
\text { CsAox2FL_R }\end{array}$ & $\begin{array}{l}\text { ATAGTACCTTGGTTTTGTGTTGTTGA } \\
\text { CCAAGTAAACTTATGAAGCCCGACTTT }\end{array}$ & $\begin{array}{l}\text { RT-qPCR primers } \\
\text { Product size } 169 \mathrm{bp}\end{array}$ & \\
\hline
\end{tabular}

${ }^{\mathrm{a}}$ Codes for mixed base sites are $\mathrm{R}=\mathrm{A}$ or $\mathrm{G}, \mathrm{W}=\mathrm{A}$ or $\mathrm{T}$, and $\mathrm{V}=\mathrm{A}$ or $\mathrm{C}$ or $\mathrm{G}$
(NP_188875), AOX1c (NP_189399), and AOX2 (NP_201226); Candida albicans AOX0a (AAC98914) and AOX0b (AAF21993); C. lanatus AOX2 (AEN99850); Cicer arietinum AOX1 (XP_004512369), AOX2a (XP_004504796), and AOX2b (XP_004504799); Cucumis sativus AOX2 (AAP33163); Chlamydomonas reinhardtii AOX0a (AAG33633) and AOX0b (AAG33634); Crassostrea gigas AOX (ACL31211); Glycine max AOX1 (NP_001236166), AOX2a (AAB97285) and AOX2b (AAB97286); Medicago sativa AOX1 (AGQ42774), AOX2a (AGQ42775), AOX2b1 (AGQ42776), and AOX2b2 (AGQ42777); Neurospora crassa AOX (AAC37481); Novosphingobium aromaticivorans DSM 12444 AOX (YP_496850); Trypanosoma brucei brucei (XP_822944); Vigna unguiculata AOX1 (AAZ09196), AOX2a (ABM66368) and AOX2b (AAZ09195). The AOX2 protein from C. melo (MELO3C027020P1) was identified in a genomic database (http://melonomics.net/) and the AOX proteins from Cajanus cajan, Lotus japonicus, Medicago truncatula, and Phaseolus vulgaris were obtained from genomic databases as described by Cavalcanti et al. (2013). Classification of AOX proteins from higher plants, C. albicans and C. reinhardtii, was according to Considine et al. (2002). Classification of AOX proteins from the remaining organisms is consistent with the accession description at NCBI GeneBank records. Sequences of AOX proteins were used to construct the phylogenetic tree (Supplementary file 1).

\section{Genome-Wide Identification of Cucumber AOX Genes}

To identify genomic regions carrying AOX, the representative set of 42 AOX protein sequences (described above) were blasted against local database with three whole-genome sequences of cucumber: line B10 (Wóycicki et al. 2011; http:// csgenome.sggw.pl/), line 9930 (Huang et al. 2009; http:// www.icugi.org/), and line Gy14 (Yang et al. 2012; http:// cucumber.vcru.wisc.edu/) using default settings.

\section{Phylogenetic and Comparative Protein Analysis}

A phylogenetic tree of the 42 AOX proteins from 12 different higher plants of the Cucurbitales, Fabales, and Brassicales; fungi ( $N$. crassa and $C$. albicans); green algae (C. reinhardtii); eubacteria (N. aromaticivorans); protists (T. brucei), and animalia (C. gigas) was constructed by the neighbor-joining method (Saitou and Nei 1987) with bootstrap values (1,000 replicates) shown next to the branches (Felsenstein 1985) using the MEGA6 program (Tamura et al. 2013). The evolutionary distances were computed using the Poisson correction method (Zuckerkandl and Pauling 1965) and are in the units of the number of amino acid substitutions per site. All ambiguous positions were removed for each sequence pair.

Detailed analysis of the cucurbit AOX sequences (Cucumis sativa, C. melo, and C. lanatus) were performed using the model proposed by Costa et al. (2014). Due to the broad diversity in the first 100 amino acids of the AOX protein sequences for comparative analysis the conserved fragment of AOX sequence (101$354 \mathrm{aa}$ ) was used. For 'sequence harmony' (SH) methodology (Feenstra et al. 2007) the set of 67 AOX2a-c subtype proteins (prepared by Costa et al. (2014)) and SeqHarm version 1.1 (http://www.ibi.vu.nl/programs/seqharmwww/) was carried out. It is assumed that the SH score of 0.2 points out the sites which are rated as exhibiting relevant differences between the compared groups of sequences.

\section{Real-Time qPCR}

Total RNA was isolated using Trizol method (Concert ${ }^{\mathrm{TM}}$ Plant RNA Reagent, Invitrogen). RNA was treated with DNaseI 
(TURBO DNA-free kit, Ambion Inc., Austin, TX, USA) and the PCR checked for lack of DNA contamination. The concentration and the quality of RNA (260/280 and 260/230 ratios) were measured before and after DNaseI treatment with the NanoDrop 2000 Spectrophotometer (Thermo Fisher Scientific, Waltham, MA, USA). The concentration of pure RNA was adjusted to $300 \mathrm{ng} / \mu \mathrm{L}$. cDNA was synthesized using Transcriptor High Fidelity cDNA Synthesis Kit (Roche, Basel, Switzerland) in a $20-\mu$ l reaction using oligo(dT) primers according to manufacturer's instructions.

Quantitative real-time reverse transcriptase PCR (RTqPCR) method was applied to compare AOX transcript level in the MSC mutants and control line B (wild-type) plants grown in optimal phytotron conditions and in line B under cold stress. All RT-qPCR assays were performed using three biological replications with three technical replicates for each tested line and growth conditions. Analysis was carried out using diluted cDNA $(1: 11.5)$ reverse transcribed from $2.1 \mu \mathrm{g}$ of total RNA. For RT-qPCR $4 \mu$ of cDNA was used. The expression study was carried out using CFX96 Touch cycler (Bio-Rad Laboratories, Hercules, CA, USA) with Master Mix Maxima SybrGreen qPCR MM 2× ROX (Thermo Fisher Scientific, Waltham, MA, USA) according to the manufacturer's instructions. RT-qPCR program was $50{ }^{\circ} \mathrm{C}$ for $2 \mathrm{~min}$ to activate Maxima DNA polymerase, $95{ }^{\circ} \mathrm{C}$ for $10 \mathrm{~min}$, followed by 40 thermal cycles of $15 \mathrm{~s}$ at $95^{\circ} \mathrm{C}$ and $1 \mathrm{~min}$ at $58{ }^{\circ} \mathrm{C}$. Melting curve analysis was performed immediately after the RT-qPCR. The temperature range used for the melting curve generation was from 70 to $95^{\circ} \mathrm{C}$. Parameters of RTqPCR were established by series of preliminary experiments with various PCR cycle numbers and annealing temperature gradients $\left(55-65^{\circ} \mathrm{C}\right)$.

Two pairs of primers designed to opposite ends of the AOX2 transcript were used: $5^{\prime}$ end pair complementary to $5^{\prime}$ UTR region of AOX2 gene (CsAox2FL_F and CsAox2R101) and $3^{\prime}$ end pair complementary to 3' UTR region of AOX2 gene (CsAox2F1155 and CsAox2FL_R) (Table 1). The efficiency of amplification for all used RT-qPCR primers comprised within the range of $96.4-99.7 \%$.

Reference genes for data normalization were selected using the geNorm V3.4 applet (Vandesompele et al. 2002) from 13 candidate genes proposed for cucumber and tested in this study (Supplemental table S1). For stronger inference in both types of growth conditions, two reference genes were used. The most stable candidate reference genes for cucumber MSC mutants and control line B (wild-type) grown under phytotron conditions with the lowest M-value $(M=0.197)$ were $U B I-e p$ (ubiquitin extension protein) and TIP41 (TIP41-like protein family) and were used as reference genes (Supplemental table S2). For cold-treatment experiment, the greatest stability of expression $(M=0.486)$ was demonstrated for two genes, $M 2$ (cyclophilin) and $m d h G$ (glyoxysomal malate dehydrogenase), primers for the experiment were provided by PrimerDesign Ltd (Southampton, UK) (Supplemental table S2).

The mean efficiency of amplification in RT-qPCR reactions was assessed using LinRegPCRv2013.1 (Ramakers et al. 2003) based on linear regression calculated for the slope of the regression line in the exponential growth phase of the product for each sample individually. Relative normalized expression ( $2^{-\Delta \Delta \mathrm{Ct}}$ method) of Aox 2 transcript and statistical analysis (Student's $t$ test) to determine significance of differences were performed using the CFX Manager TM software 3.1 (Bio-Rad Laboratories).

\section{Immunoblotting Analyses}

For leaves and Flowers of Field Grown Plants Total plant proteins were extracted from leaves and flowers collected from plants grown in the field. Briefly, collected tissue frozen in liquid nitrogen was ground using mortar and pestle and extracted in buffer (100 mM Tris, $200 \mathrm{mM} \mathrm{KCl,} 10 \mathrm{mM}$ EDTA, $1 \%$ $(v / v)$ Triton $\mathrm{X}-100$, and $\mathrm{pH} 8.0)$. Protein content was determined by the method of Bradford (Bradford 1976) and verified by SDS-PAGE and Coomassie staining. For immunoblotting analysis, 30-40 $\mu \mathrm{g}$ of total plant proteins were loaded on $15 \%$ SDS PAGE gels, electrophoresed, and blotted on the Hybond C Extra nitrocellulose membrane (GE Healthcare, Little Chalfont, UK). Membranes were blocked using $5 \%$ milk powder and probed with antibodies according to membrane manufacturer's instructions. Both primary and secondary antibodies (anti-AOX 1:200 and anti-porin 1:500) were diluted in PBS containing $0.1 \%$ Tween. Immunoreactive proteins were visualized by chemiluminescence on photographic film. Mouse monoclonal antibodies anti-AOX and anti-porin (Elthon et al. 1989; Blake et al. 2007) were kindly provided by Prof. Tom Elthon, University of Nebraska.

For Plants Grown Under Controlled Conditions Total plant proteins were extracted in buffer $(2 \% \mathrm{w} / \mathrm{v}$ SDS, $50 \mathrm{mM}$ TrisHCl, $\mathrm{pH} 7.6$, and $1 \mathrm{mM} \beta$-mercaptoetanol). The final concentration of total protein was leveled with $\mathrm{RC} \mathrm{DC}$

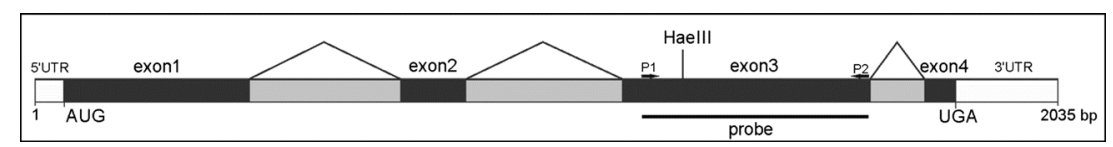

Fig. 1 The structure of the cucumber AOX2 gene (NCBI Gen Bank Acc. No. AY258276). The cucumber AOX2 gene $(2,035 \mathrm{bp})$ possesses four exons and three introns with $55 \mathrm{bp} \mathrm{5'} \mathrm{UTR} \mathrm{and} 200 \mathrm{bp} \mathrm{3'}$ UTR regions. P1 and $\mathrm{P} 2$ are degenerated primers used to amplify conserved $446 \mathrm{bp}$ fragment of AOX gene (called 'probe', used in hybridization experiments) 
Fig. 2 Southern blot hybridizations from hybridization of nick-translated $446 \mathrm{bp} \mathrm{AOX}$ clone ('probe', Fig. 1) as an evidence for the presence of a single AOX gene in cucumber. a Cucumber line $\mathrm{B}$, melon 'Iroqouis', watermelon 'Dixielee', Cucurbita moschata 'Butternut', and Cucurbita pepo 'Dark Green Zucchini' DNA digested with EcoRI and b cucumber line B DNA digested with nine different restriction enzymes

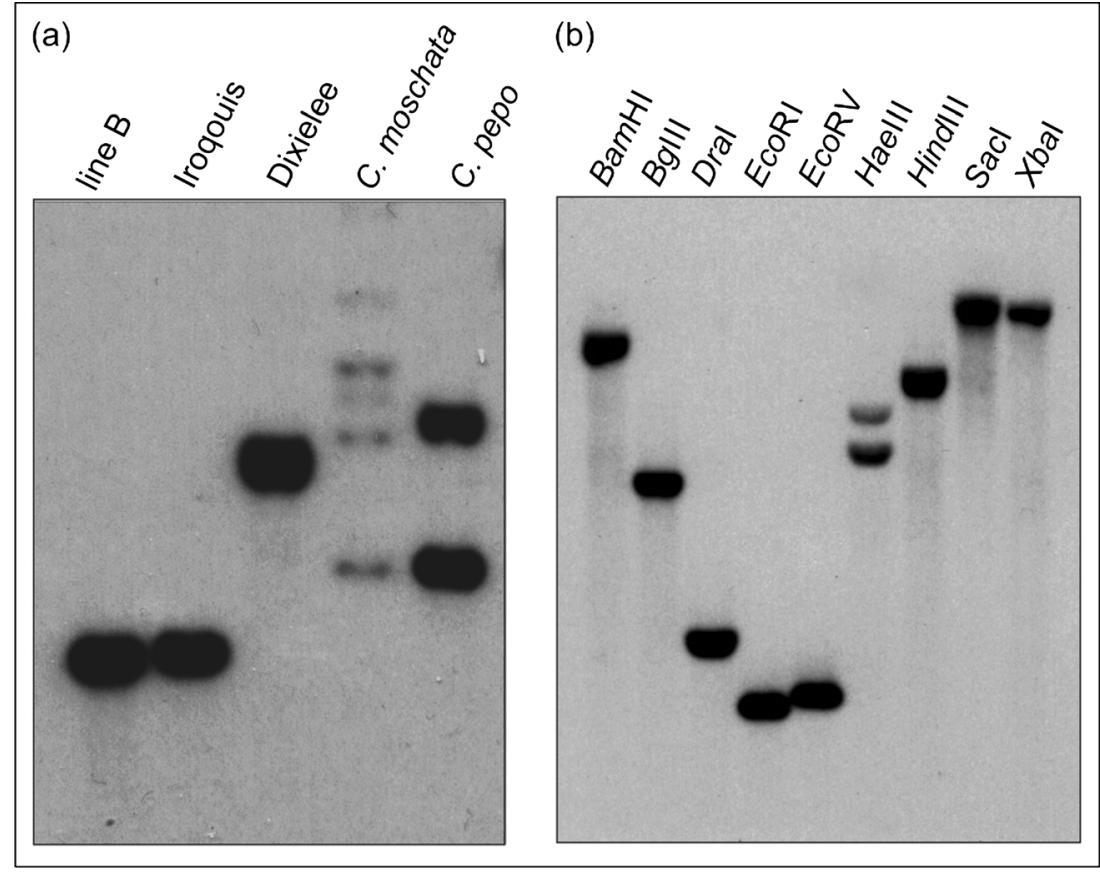

Protein Assay Kit (Bio-Rad Laboratories) according to manufacturer's protocol. For immunoblotting analysis, $25 \mu \mathrm{g}$ of total plant proteins were loaded on SDS PAGE gels (4\% stacking and $12 \%$ running gel), electrophoresed, and transferred on the PVDF membrane (Bio-Rad Laboratories). Ponceau S (Sigma-Aldrich) membrane staining was performed as a loading control. Membranes were blocked using $5 \%$ Blotting Grade Blocker Non Fat Dry Milk (Bio-Rad Laboratories), washed, and probed with antibodies: rabbit polyclonal antibodies anti-AOX1/2 (Agrisera, Vännäs, Sweden) and for cold experiment with line B also mouse monoclonal antibodies anti-Alpha-tubulin (Invitrogen). Antibodies were diluted anti-AOX1/2 1:1,000 and antiAlpha-tubulin 1:250 in TBS-T and incubated with membrane for $1.5 \mathrm{~h}$. Horseradish peroxidase conjugated goat anti-rabbit $(1: 25,000)$ or rabbit anti-mouse $(1: 5,000)$ antibodies (Agrisera) were used as secondary antibodies. Both were diluted in HST buffer $(5 \mathrm{mM}$ TrisHCl pH 7.5, $1 \mathrm{M} \mathrm{NaCl}$, and $0.5 \%(w / v)$ Tween 20$)$ and incubated with membrane for $1 \mathrm{~h}$. The chemiluminescence reaction was carried out using ECL Amersham Prime Western Blotting Detection Reagent (GE Healthcare) according to manufacturer's protocol. Immunodetection was visualized directly on the membrane using ChemiDoc XRS+ system (Bio-Rad Laboratories). Western blots for cold-treated plants were performed in two biological replications with two technical replicates each. The results of experiment with cold-treated line B (wild-type) were quantified by densitometry $(n=4)$ using ChemiDoc XRS+ system (Bio-Rad Laboratories) and differences between successive time points after chilling were calculated by $t$ Student test using Statistica version 10 (StatSoft, Tulsa, OK, USA).

\section{Results}

\section{Cloning of AOX Genes from Cucumber}

Primers P1 and P2, designed to conserved regions of AOX proteins (Saisho et al. 1997), amplified a single 446 bp fragment from cucumber. DNA of 15 putative AOX clones from two independent PCR reactions were sequenced to confirm their identities. All sequenced clones were identical, suggesting that cucumber possesses a single AOX gene. A larger (3, $474 \mathrm{bp}$ ) genomic clone of AOX was isolated from vectorette libraries of cucumber. 3'and 5' RACE was used to clone the full length AOX transcript. Based on the genomic (2,035 bp) and full length cDNA $(1,551 \mathrm{bp})$ sequences, the structure of cucumber AOX gene was established (Fig. 1). The sequence of AOX gene with coding sequence was deposited in NCBI as accession AY258276. The cucumber AOX gene possesses four exons and three introns with $55 \mathrm{bp} \mathrm{5}$ ' UTR and $200 \mathrm{bp}$ 3' UTR regions, similar to other plants (Fig. 1).

Fig. 3 Phylogenetic tree of 42 AOX proteins from 12 different higher plant species of the Cucurbitales, Fabales, and Brassicales; fungi (N. crassa and C. albicans); green algae (C. reinhardtii); eubacteria ( $N$. aromaticivorans); protists (T. brucei), and animalia (C. gigas). Classification of higher plants, C. albicans, and C. reinhardtii AOX proteins is according to Considine et al. (2002). Classification of AOX proteins from other organisms is consistent with the protein sequence description at the NCBI GeneBank. The tree was obtained by the Neighbor-Joining method with 1,000 bootstrap replicates using the MEGA6 program (Tamura et al. 2013). Branches are drawn in proportion to genetic distance according to the scale shown in the bottom of the figure. The tree was constructed according to sequence data indicated in the Supplementary file 1 


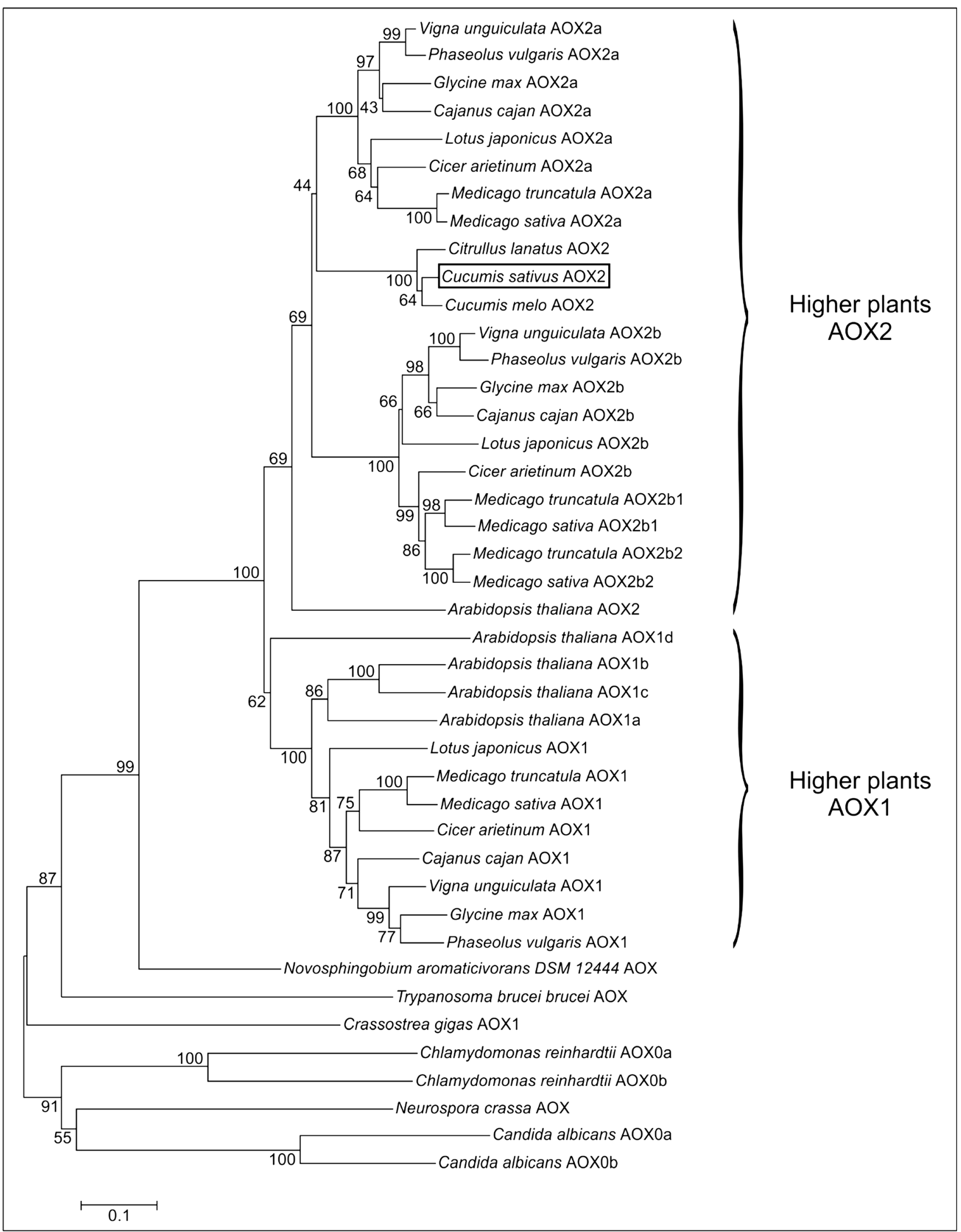




\section{Cucumber Possesses a Single AOX Gene}

Southern hybridization of exon 3 of AOX (Saisho et al. 1997, Fig. 1) was used to assess numbers of AOX genes in the cucurbits. The results revealed a single band for cucumber, melon, and watermelon. However, three major and two weaker bands were detected for C. moschata and two bands for C. pepo (Fig. 2a). When the same probe was hybridized to cucumber, DNAs singly digested with nine enzymes revealed a single band for eight restriction enzymes and two bands for HaeIII, revealing an internal HaeIII restriction site within the probe region (Fig. 2b). Presence of this HaeIII site was confirmed later by in silico restriction sites analysis in the genomic sequence. The same AOX exon three probe was hybridized to the cucumber fosmid library and the single clone carrying the AOX gene was identified. This AOX-carrying fosmid was sequenced and contained the same $\mathrm{AOX}$ sequence as cloned by PCR. These results strongly support a single AOX gene in cucumber, melon, and watermelon, and more than one AOX gene in Cucurbita (the representative results for EcoRI digestion are shown in Fig. 2a).

\section{Cucumber, Melon, and Watermelon AOX Genes Encode AOX2}

Based on the full length cDNA sequence, the protein sequence of cucumber AOX was predicted to have 346 amino acids (NCBI GeneBank Accession APP33163). The optimal phylogenetic tree based on the amino acid sequences of 42 AOX proteins from diverse monocots and dicots had sum of branch length 6.686 (Fig. 3). Cucumber AOX formed a new branch and was placed with AOX proteins from melon and watermelon in the higher plants AOX2 cluster, between AOX2a and AOX2b subgroup as distinguished by Considine et al. (2002) (Fig. 3).

\section{Identification of Amino Acids Specific to AOX2 in Cucumber, Melon, and Watermelon}

Analysis of the protein sequences based on the classification proposed by Costa et. al. (2014) showed that the AOX2 proteins of C. sativus, C. melo, and C. lanatus have almost all the amino acids specific for the AOX2a-c subtype, but are also polymorphic for 16 amino acids sites within the conservative AOX region. The specificities of eight sites were confirmed using 'sequence harmony' (SH) methodology (Feenstra et al. 2007). Four of the differences possess relatively strong reliability parameters in $\mathrm{SH} \leq 0.13$ and four relevant differences $\mathrm{SH}=0.17$ (AOX2a-c consensus positions: 147, 159, 230, 347 and 103, 111, 180, 289, respectively) (Fig. 4, Supplemental table S3, and Supplementary file 2).

Although none of the eight polymorphic amino acids are located in the four highly conserved regions of AOX, some are close to highly conserved and functionally important amino acids. Amino acids in position 103,111, and $147 *$ (* indicates positions with relatively strong reliability parameters at $\mathrm{SH} \leq 0.13$ ) are in the neighborhood of conserved cysteine residue CysI (C127) associated with post-translational modifications (Berthold et al. 2000; Costa et al. 2014). Residues in position $159^{*}, 289$, and $347^{*}$ are located close to the second conserved cysteine CysII (C177), LEEEA region, and RADE_H region, respectively. Two amino acids situated in position 180 and $230^{*}$ were found in close proximity to the functional regions: residue at position 180 is situated between second highly conserved cysteine CysII (C177) and the LET region (involved in iron-binding) and amino acid at position $230^{*}$ is situated close to NERMHL region (utilized to form the four-helix bundle required for iron-binding) (Berthold et al. 2000). Therefore, cucumber, melon, and watermelon possess a single AOX belonging to the AOX2a-c group with several unique amino acid residues.

\section{Chromosomal Localization of Cucumber AOX2}

Using the three available cucumber genomic sequences [line 9930 (Huang et al. 2009), line Gy14 (Yang et al. 2012), and line B10 (Wóycicki et al. 2011)], we confirmed that there is only one AOX2 gene in the cucumber genome and no AOX1 genes. Analysis of the genomes with chromosomal versions available (line 9930 and Gy14) showed that AOX2 gene is located in the middle of the upper arm of chromosome 4 (Table 2).

\section{Expression of AOX2}

Initial comparative analysis performed for field-grown plants of line B (wild-type) and mitochondrial mutant MSC16 revealed that cucumber Aox2 transcripts were detected both in leaves and in male flowers with a higher level in MSC16 (Fig. 5a). Western blots confirmed this result showing higher AOX2 abundance in the mitochondrial mutant MSC16 (Fig. 5b).

Detailed analysis of the expression of AOX2 in cucumber line B (wild-type) at the transcript and protein level showed that the Aox2 gene is upregulated by cold stress (Fig. 6). The amount of Aox2 transcripts was increasing rapidly (172-fold, $p<0.001)$ immediately after chilling and decreasing with each passing day from the occurrence of cold stress (Fig. 6a). Western blot confirmed that cucumber AOX2 is upregulated by cold stress and statistically significant differences were revealed (Fig. 6b, c). The amount of AOX2 significantly increased $1 \mathrm{~h}$ after chilling $(1.8$-fold, $p<0.05)$ compared to the AOX2 amount before cold treatment. The highest level of AOX2 was observed 48 h (2 days) after chilling (6.3-fold increase, $p<0.001)$. With time, the amount thereof was reduced, wherein the level $144 \mathrm{~h}$ ( 6 days) after cold treatment 


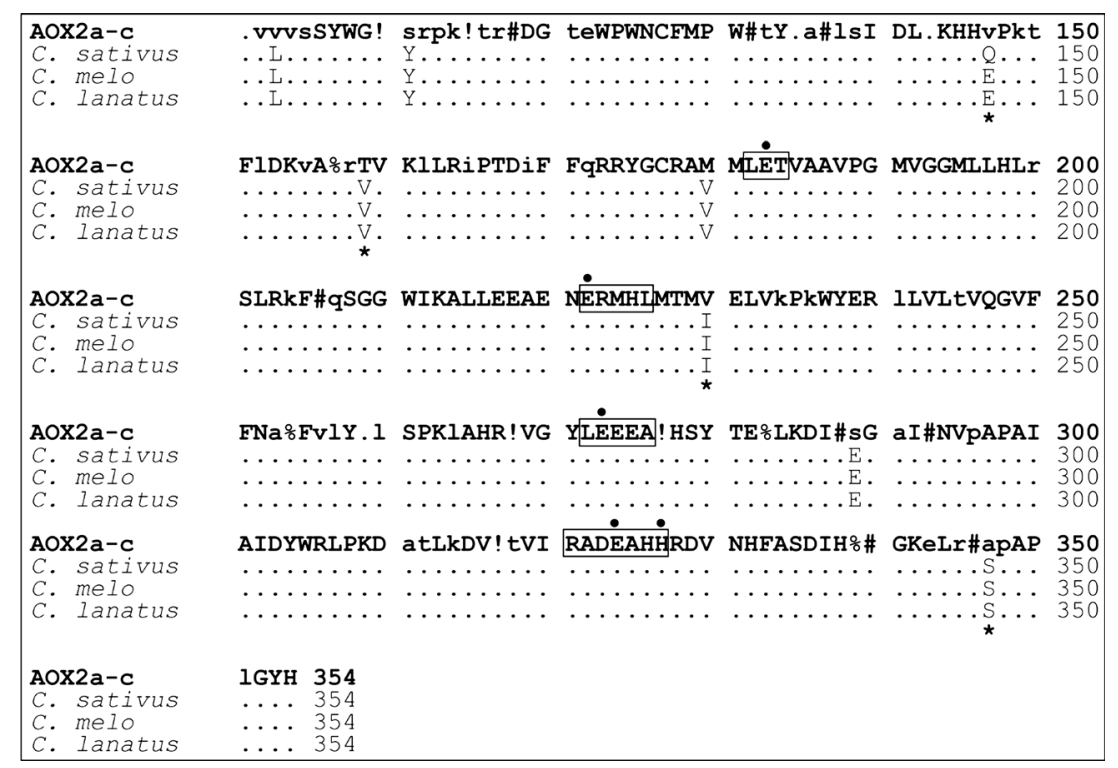

Fig. 4 Amino acid sites unique to AOX2 in cucumber, melon, and watermelon. An alignment of the conservative fragment (101-354 aa) of AOX2a-c consensus sequence (Costa et al. 2014) and cucumber, melon, and watermelon corresponding AOX fragments appear with eight specific amino acids residues. Indicated amino acids sites were rated as exhibiting relevant differences using the 'sequence harmony' (SH) methodology (Feenstra et al. 2007). In addition, those presenting the strong reliability parameters in $\mathrm{SH} \leq 0.13$ are marked with an asterisk. Figure was prepared by using the model proposed by Costa et al. (2014).

was still relatively high compared to the level before chilling (4.9-fold increase, $p<0.001$ ) (Fig. 6b, c).

Extended comparative analysis performed for both the line $\mathrm{B}$ (wild-type) and MSC lines 3, 12, and 16 showed that all MSC lines grown in optimal conditions revealed elevated expression level of Aox2 transcripts (2.3- to 2.5-fold increase, at least $p<0.05$ ) relative to untreated wild-type, control line B (Fig. 7a).
Four highly conserved AOX active regions (LET, NERMHL, LEEEA, and RADE_H) were marked by frames, glutamic acid (E) and histidine $(\mathrm{H})$ amino acid residues involved in iron-binding were indicated by black circles (Berthold et al. 2000). Capital letters at the specific sites represent the most frequently seen amino acids. Consensus symbols used in the AOX2a-c consensus sequences: exclamation mark is I (Isoleucine), or V (valine); percent sign is $\mathrm{F}$ (phenylalanine), or $\mathrm{Y}$ (tyrosine); number sign is $\mathrm{N}$ (asparagine), D (aspartic acid), Q (glutamine), or E (glutamic acid). For more details, the reader is referred to the Supplementary file 2

No significant differences were observed in Aox2 expression among the MSC lines (Fig. 7a). Moreover, Western blot analysis demonstrated that in all MSC lines 3, 12, and 16 AOX2 protein was detected both before and after cold treatment at a consistently high level with the highest amount observed $48 \mathrm{~h}$ (2 days) after cold treatment (Fig. 7b), which is similar to observations made for control line B.
Table 2 Chromosomal positions of AOX2 gene in the cucumber genome line 9933 version 2 (http://www.icugi.org/) and Gy14 assembly version 1 (http:// cucumber.vcru.wisc.edu/) based on BLAST search

\begin{tabular}{|c|c|c|c|c|c|c|c|}
\hline \multirow[t]{2}{*}{ Chromosome } & \multirow[t]{2}{*}{$\begin{array}{l}\text { AOX } 2 \text { gene } \\
\text { region }\end{array}$} & \multicolumn{2}{|c|}{$\begin{array}{l}\text { Line } 9930 \\
\text { genome position } \\
\text { (Csa4M109010.1) }\end{array}$} & \multicolumn{2}{|c|}{$\begin{array}{l}\text { Line Gy14 } \\
\text { genome position } \\
\text { (Cucsa.398150.1) }\end{array}$} & \multirow[t]{2}{*}{$\begin{array}{l}\text { Starting } \\
\text { gene } \\
\text { position }\end{array}$} & \multirow[t]{2}{*}{$\begin{array}{l}\text { Ending } \\
\text { gene } \\
\text { position }\end{array}$} \\
\hline & & Starting & Ending & Starting & Ending & & \\
\hline \multirow[t]{10}{*}{$\mathrm{Chr} 4^{\mathrm{a}}$} & $5^{\prime}$ UTR & $6,991,492$ & $6,991,438$ & $6,688,767$ & $6,688,713$ & -55 & -1 \\
\hline & Exon1 & $6,991,437$ & $6,991,075$ & $6,688,712$ & $6,688,350$ & 1 & 363 \\
\hline & Intron1 & $6,991,074$ & $6,990,769$ & $6,688,349$ & $6,688,044$ & 364 & 669 \\
\hline & Exon 2 & $6,990,768$ & $6,990,640$ & $6,688,043$ & $6,687,915$ & 670 & 798 \\
\hline & Intron 2 & $6,990,639$ & $6,990,322$ & $6,687,914$ & $6,687,597$ & 799 & 1,117 \\
\hline & Exon 3 & $6,990,321$ & $6,989,833$ & $6,687,596$ & $6,687,108$ & 1,118 & 1,607 \\
\hline & Intron 3 & $6,989,832$ & $6,989,718$ & $6,687,107$ & $6,686,993$ & 1,608 & 1,723 \\
\hline & Exon 4 & $6,989,717$ & $6,989,658$ & $6,686,992$ & $6,686,933$ & 1,724 & 1,784 \\
\hline & 3' UTR & $6,989,657$ & $6,989,458$ & $6,686,932$ & $6,686,733$ & 1,785 & 1,985 \\
\hline & AOX fosmid & $7,024,359$ & $6,983,645$ & $6,720,115$ & $6,681,175$ & 1 & 40,869 \\
\hline
\end{tabular}

${ }^{\text {a }}$ Estimated size of chromosome 4 of line 9930 is 23,425,844 and Gy14 is 23,376,920 bp, AOX2 gene is present in the reverse orientation in both genomes 


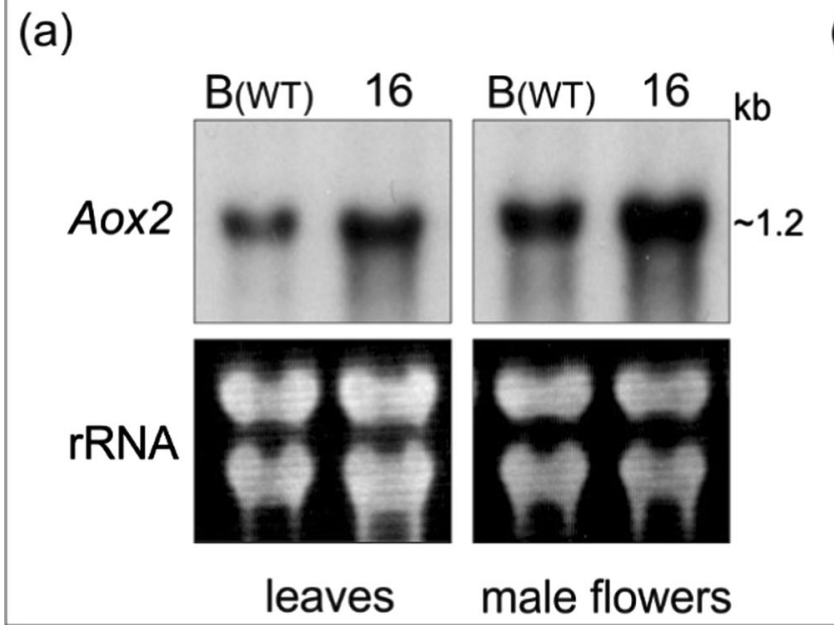

Fig. 5 Expression of AOX2 in field grown plants of cucumber and in leaves and flowers of control line B (wild-type) and mutant MSC16. Revealing higher amounts of Aox 2 transcripts by Northern-blot analysis $\mathbf{a}$ and $\mathrm{AOX} 2$ protein by Western blot $\mathbf{b}$ in MSC16. a Relative amounts of alternative oxidase transcript in total RNA extracts. Approximate sizes of (b)

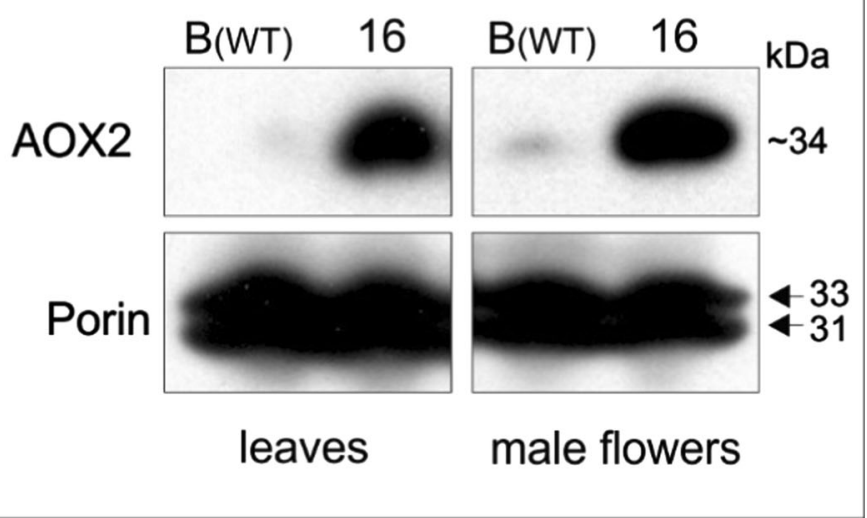

Aox2 transcript in kilobases is shown on right. Gel picture at bottom shows ethidium bromide stained rRNA showing equal loading of RNA samples. b Relative amounts of alternative oxidase and porin in total protein extracts. Approximate sizes of polypeptides in kilodaltons are shown on right. Porin was used as internal control

\section{Discussion}

Two AOX subfamilies (AOX1 and AOX2) are present in angiosperms (Considine et al. 2002). In monocots, duplications of AOX1 gene are common and AOX2 subfamily was lost early in evolution (Costa et al. 2014). In eudicots, both subfamilies AOX1 and AOX2 are present. Different AOX1 subtypes being a result of duplications are well known and duplications of AOX2 were recently classified into two subtypes-AOX2a-c and stress-responsive AOX2d (Costa et al. 2014).

In this study, we identified a single AOX2 gene after carefully evaluating three available genomic sequences of cucumber (line 9930, line Gy14, and line B10), performing Southern blot hybridizations, and screening a cucumber fosmid library. There was no evidence for AOX1 gene(s) and no evidence for AOX2 gene duplication(s) in cucumber. The alignment of the consensus sequences of AOX2a-c (Costa et al. 2014) and cucumber, melon, and watermelon AOX proteins demonstrates agreement for all residues specific for $\mathrm{AOX} 2 \mathrm{a}-\mathrm{c}$ subtype. However, we identified variation for 16 specific amino acids in conserved regions of the AOX2 protein (101-354 aa). Eight were identified as exhibiting relevant differences between the consensus sequence of AOX2a-c subtype (Costa et al. 2014) and cucumber, melon, and watermelon using the 'sequence harmony' (SH) methodology (Feenstra et al. 2007). Although six of the differences were not located in the immediate vicinity of the functional regions (Berthold et al. 2000; Costa et al. 2014), their effect on AOX2 protein structure could not be excluded. Two amino acids (position: 180, $230^{*}$ ) were located close to important functional regions of $\mathrm{AOX}$ at position 180 situated between the second highly conserved cysteine CysII (C177) and the LET region (involved in iron-binding) and position $230 *$ close to NERMHL region utilized to form the four-helix bundle required for ironbinding (Berthold et al. 2000). Both substitutions demonstrated compliance with residues specific for AOX1d: 180 with residue found in monocot AOX1d and 230* residue frequently occurring in eudicot AOX1d (Costa et al. 2014). These findings indicate that cucumber likely lost AOX1 gene(s) and did not experience AOX2 duplication(s), resulting in a single AOX2 gene that assumes the functions of AOX1 gene(s) for stress responsiveness. However, it is also possible that cucumber AOX2 gene is the primary AOX gene that did not undergo any divergence and its expression covers all AOX functions.

Besides the AOX1 genes, there are examples of AOX2 genes regulated by stress in A. thaliana and leguminous species (Clifton et al. 2005; Costa et al. 2010; Cavalcanti et al. 2013). However, all stress-regulated AOX2 genes were classified based on protein similarity into AOX2d subtype (Costa et al. 2014). In this study, we provide evidence that the cucumber AOX2 of AOX2a-c subtype is regulated by cold stress, induced by chilling in control line B (wild-type) and upregulated before and after cold treatment in the three MSC mitochondrial mutants. The study of Lei et al. (2010) revealed that cucumber seedlings treated with combination of low temperature and SA show enhanced expression and accumulation of AOX but did not define what AOX. In this study we proved that cucumber has only one AOX2a-c. This clearly shows that AOX2a-c genes can be stress-responsive. This finding extends the observation that only AOX2d genes can be stressresponsive (Costa et al. 2014). The findings that AOX2 in cucumber is stress-responsive (chilling), SA regulated, belongs to AOX2a-c subtype with specific amino acids residues 

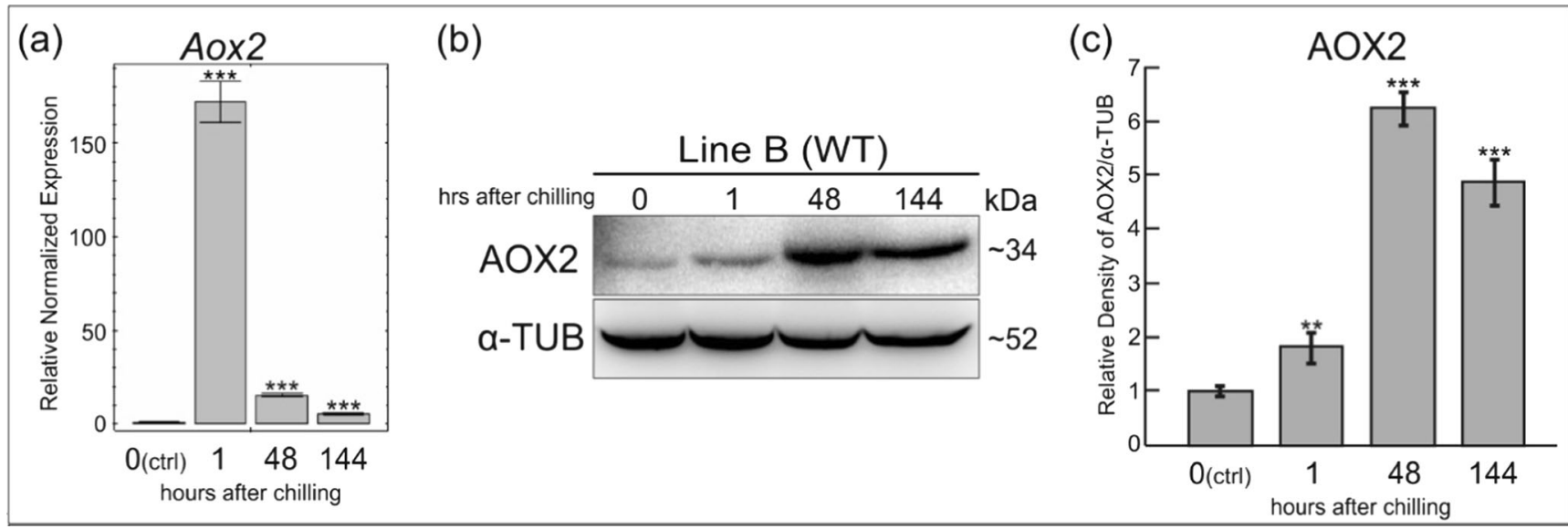

Fig. 6 Expression AOX2 in cucumber line B after cold treatment. Both analyses RT-qPCR (a) and Western blot (b and $\mathbf{c}$ ) revealed that cucumber AOX2 is cold-responsive. Rapid increase (172-fold, $p<0.001)$ of Aox2 transcript abundance after chilling was observed (a) and the significantly highest amount of AOX2 protein $(6.3$-fold increase, $p<0.001)$ was proved $48 \mathrm{~h}$ ( 2 days) after chilling (b and $\mathbf{c})$. Differences between stages after chilling were referenced to the state before chilling marked as ' 0 (ctrl)'. The following ranges of $P$ value were defined: ${ }^{*} p<0.05$, $* * p<0.01$, and $* * * p<0.001$. a RT-qPCR results obtained with CsAox2FL_F and CsAox2R101 primers designed to 5' end of Aox2.

demonstrate that the cucumber AOX2 functions uniquely from previously described AOX2 genes.

Juszczuk et al. (2007) and Szal et al. (2009) studied hydroponically grown cucumber and showed that the AOX protein level was higher in MSC16 compared to wild-type line B. Florez-Sarasa et al. (2009) demonstrated that despite higher AOX abundance, there was no difference in AOX activity in wild-type line B and MSC16 mutant. When these results were published, it was not known that cucumber possesses only a single AOX gene and therefore it was not possible to recognize that observed differences are effects of expression of the AOX2 gene and not AOX1. Moreover, the study was performed on a single mitochondrial mutant (MSC16); in our study we showed that three distinct MSC mutants characterized by unique rearrangements of their mtDNA (Bartoszewski et al. 2004) express higher level of AOX2. We also demonstrated that elevated levels of AOX2 protein is characteristic for all three MSC lines both before and after chilling.

We demonstrated that previously described classifications for alternative oxidases in higher plants do not fit cucumber, because of (1) the presence of a single AOX gene assigned to the subtype AOX2a-c, (2) AOX2 expression in cucumber is induced by cold stress suggesting it carries stress-related functions. We also found that three distinct MSC mutants, including MSC16 that possesses negatively affected respiratory complex I and increased ROS level (Juszczuk et al. 2007; Szal et al. 2009), show upregulation of AOX2a-c. These
Primers specific to UBI-ep and TIP41 were used as reference genes (Supplemental tables S1 and S2). The diagram shows the average relative normalized expression to control (pre-chilling). Bars represent standard error of the mean (SEM). b Western blot confirmed cold regulation of AOX2. Alpha-tubulin was used as an internal control. Approximate size of polypeptides in kilodaltons are shown on right. c Densitometry quantification of Western blot analysis $(n=4)$ performed using ChemiDoc XRS+ system (Bio-Rad Laboratories). Relative amount of AOX2 was normalized to alpha-tubulin findings revealed that cucumber represents an interesting model to study the regulation of AOX expression, especially in the acclimation of plants to different environmental conditions. To verify whether the single cucumber AOX2a-c subtype is stress-responsive we decided to use cold treatment because cucumber is a thermophilic plant sensitive to low temperatures. It must be noted that elevated AOX expression was observed in a broad range of stress conditions (Clifton et al. 2005) and therefore, the next step should be taken to verify the regulation of the cucumber AOX2 expression by other stresses. However, it should be emphasized that this is the first report showing in a simple and clear way that the alternative oxidase from $\mathrm{AOX} 2 \mathrm{a}-\mathrm{c}$ subtype may respond to chilling stress. Also identification of cucumber AOX2 mutants or development of transgenic lines with downregulated and overexpressed AOX2 would benefit further studies. Recent studies indicate that the regulation of the AOX1a in A. thaliana not only alters auxin homeostasis, allowing plants to respond rapidly to environmental changes but also regulates the growth and development (Ivanova et al. 2014). Therefore, it is possible that increased expression of AOX2 in the cucumber MSC mitochondrial mutants can alter auxin homeostasis and result in their slower germination, weaker growth, and organ deformation.

There are several studies providing insights about nuclear response to mitochondrial stress where mitochondrial mutants of model plant species, including Arabidopsis, tobacco, and maize, were used (Newton et al. 1990; 


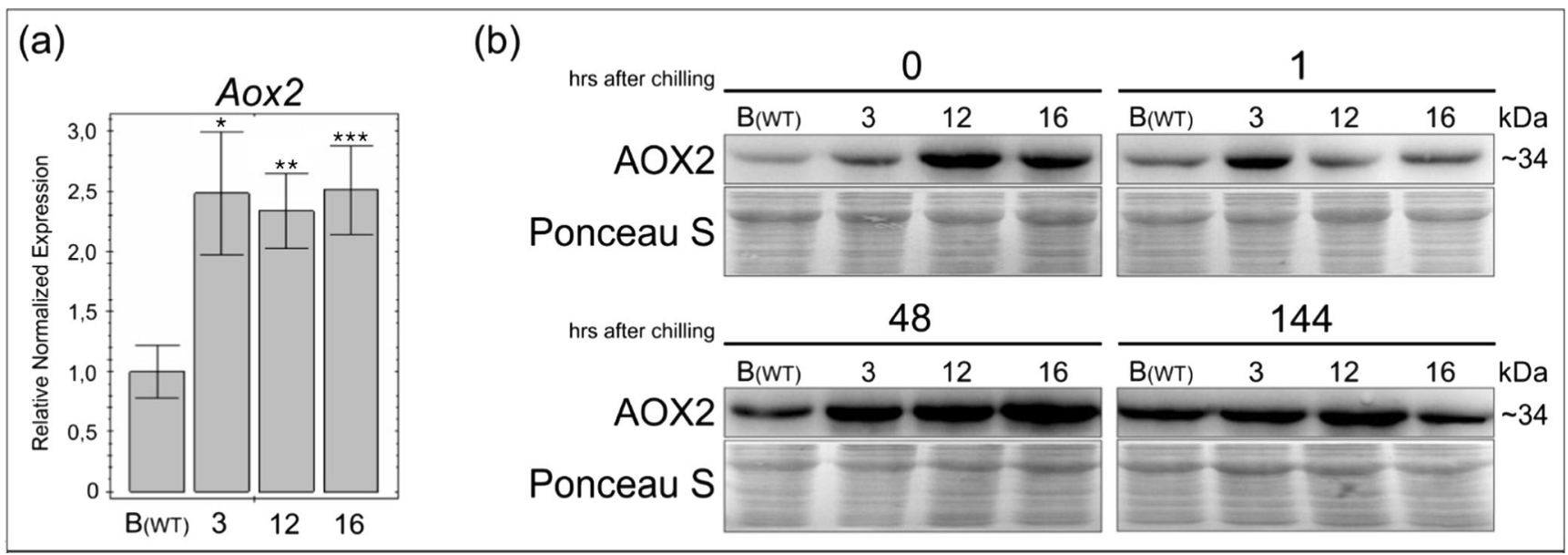

Fig. 7 Expression of AOX2 in cucumber control line B (wild-type) and MSC lines. AOX2 is upregulated in MSC lines 3, 12, and 16 both before and after chilling compared to control line $\mathrm{B}\left(\mathrm{B}_{\mathrm{WT}}\right)$. a Results of RTqPCR analysis performed with primers designed to $5^{\prime}$ end of Aox2 (CsAox2FL_F and CsAox2R101). Primers specific to $M 2$ and $m d h G$ were used as reference genes (Supplemental table S1 and S2). The diagram shows Aox2, the average relative expression in MSC mutants before chilling, referenced to the control line $\mathrm{B}$ ( $\mathrm{B}_{\mathrm{WT}}$, referred to as 1).

Kanazawa et al. 1994; Kuzmin et al. 2004; Shedge et al. 2007, 2010). The disadvantage of these studies is that these plant species possess maternally transmitted both chloroplast and mitochondria that make it difficult to distinguish clearly chloroplast from mitochondrial effects. Cucumber possesses paternally transmitted mitochondria, making it possible to separate putative chloroplast and mitochondrial effects at the genetics level by reciprocal crosses. Another limitation in mitochondrial retrograde signaling studies is that very few mitochondrial mutants are available and there is no effective method to obtain mitochondrial mutants. In cucumber, passage of wild-type cucumber through tissue cultures may be applied to develop lines possessing distinct mtDNA rearrangements (Malepszy et al. 1996) and it has been postulated as a method to generate mitochondrial mutants (Bartoszewski et al. 2007). Such mitochondrial mutants could be interesting plant material in the study of mitochondria to nucleus cross-talk. MSC lines used in this study were developed this way. Thus, we think that cucumber is an interesting plant species to study retrograde signaling.

In conclusion, our study showed that cucumber possesses a single AOX2 gene that is stress-regulated making it easy to manipulate and interpret AOX expression. Availability of the MSC mitochondrial mutants of cucumber with upregulated expression of AOX2 even in optimal growth conditions makes cucumber an intriguing model to study AOX expression and mitochondrial retrograde signaling. A full understanding of the mechanisms related to mitochondrial retrograde signaling in crop species could lead to discovery of novel stress-response genes as potential targets for plant breeding.
Bars represent standard error of the mean (SEM). Statistical differences were confirmed using $t$ Student test and $P$ value $<0.05$ was considered as statistically significant. The following $P$ value ranges were defined: ${ }^{*} p<0.05,{ }^{*} p<0.01$, and ${ }^{* * *} p<0.001$. b AOX2 expression pattern in the MSC mutants under cold stress. Ponceau S staining was used as a loading control. Approximate size of AOX2 in kilodaltons is shown on right

Acknowledgments We thank Prof. Thomas Elthon (University of Nebraska) for providing us anti-AOX and anti-porin mouse monoclonal antibodies and Dr. Emilia J. Orzechowska (University of Warsaw, Poland) for consultation on the optimization of protein detection. This work was supported by Polish National Science Centre NCN project N N310 107740. The authors declare that there is no conflict of interest.

Disclaimer Names are necessary to report factually on available data; however, the U.S. Department of Agriculture (USDA) neither guarantees nor warrants the standard of the product, and the use of the name by USDA implies no approval of the product to the exclusion of others that may also be suitable.

Open Access This article is distributed under the terms of the Creative Commons Attribution 4.0 International License (http:// creativecommons.org/licenses/by/4.0/), which permits unrestricted use, distribution, and reproduction in any medium, provided you give appropriate credit to the original author(s) and the source, provide a link to the Creative Commons license, and indicate if changes were made.

\section{References}

Alverson AJ, Rice DW, Dickinson S, Barry K, Palmer JD (2011) Origins and recombination of the bacterial-sized multichromosomal mitochondrial genome of cucumber (Cucumis sativus). Plant Cell 23:2499-2513

Andersson M, Nordlund P (1999) A revised model of the active site of alternative oxidase. FEBS Lett 4449:17-22

Apel K, Hirt H (2004) Reactive oxygen species: metabolism, oxidative stress, and signal transduction. Annu Rev Plant Biol 55:373-399

Bartoszewski G, Malepszy S, Havey MJ (2004) Mosaic (MSC) cucumbers regenerated from independent cell cultures possess different mitochondrial rearrangements. Curr Genet 45:45-53

Bartoszewski G, Havey MJ, Ziółkowska A, Długosz M, Malepszy S (2007) The selection of mosaic (MSC) phenotype after passage of 
cucumber (Cucumis sativus L.) through cell culture-a method to obtain plant mitochondrial mutants. J Appl Genet 48:1-9

Berthold DA, Andersson ME, Nordlund P (2000) New insight into the structure and function of the alternative oxidase. Biochim Biophys Acta 1460:241-254

Blake JA, Lee KW, Morris TJ, Elthon TE (2007) Effects of turnip crinkle virus infection on the structure and function of mitochondria and expression of stress proteins in turnips. Physiol Plant 129:698-706

Borecký J, Nogueira FT, de Oliveira KA, Maia IG, Vercesi AE, Arruda P (2006) The plant energy-dissipating mitochondrial systems: depicting the genomic structure and the expression profiles of the gene families of uncoupling protein and alternative oxidase in monocots and dicots. J Exp Bot 57:849-864

Bradford MM (1976) A rapid and sensitive method for the quantitation of microgram quantities of protein utilizing the principle of protein-dye binding. Anal Biochem 72:248-254

Cavalcanti JH, Oliveira GM, Saraiva KD, Torquato JP, Maia IG, de Melo DF, Costa JH (2013) Identification of duplicated and stressinducible Aox $2 b$ gene co-expressed with Aoxl in species of the Medicago genus reveals a regulation linked to gene rearrangement in leguminous genomes. J Plant Physiol 170:1609-1619

Clifton R, Lister R, Parker KL, Sappl PG, Elhafez D, Millar AH, Day DA, Whelan J (2005) Stress-induced co-expression of alternative respiratory chain components in Arabidopsis thaliana. Plant Mol Biol 58:193-212

Considine MJ, Holtzapffel RC, Day DA, Whelan J, Millar AH (2002) Molecular distinction between alternative oxidase from monocots and dicots. Plant Physiol 129:949-953

Costa JH, Mota EF, Cambursano MV, Lauxmann MA, de Oliveira LM, Silva Lima Mda G, Orellano EG, Fernandes de Melo D (2010) Stress-induced co-expression of two alternative oxidase (VuAox1 and 2b) genes in Vigna unguiculata. J Plant Physiol 167:561-570

Costa JH, McDonald AE, Arnholdt-Schmitt B, de Melo DF (2014) A classification scheme for alternative oxidases reveals the taxonomic distribution and evolutionary history of the enzyme in angiosperms. Mitochondrion 19:172-183

Cvetkovska M, Vanlerberghe GC (2013) Alternative oxidase impacts the plant response to biotic stress by influencing the mitochondrial generation of reactive oxygen species. Plant Cell Environ 36:721-732

De Clercq I, Vermeirssen V, Van Aken O, Vandepoele K, Murcha MW, Law SR, Inzé A, Ng S, Ivanova A, Rombaut D, van de Cotte B, Jaspers P, Van de Peer Y, Kangasjärvi J, Whelan J, Van Breusegem F (2013) The membrane-bound NAC transcription factor ANAC013 functions in mitochondrial retrograde regulation of the oxidative stress response in Arabidopsis. Plant Cell 25:3472-3490

Elthon TE, McIntosh L (1987) Identification of the alternative terminal oxidase of higher plant mitochondria. Proc Natl Acad Sci U S A 84: 8399-8403

Elthon TE, Nickels RI, McIntosh L (1989) Monoclonal antibodies to the alternative oxidase of plant mitochondria. Plant Physiol 89:13111317

Feenstra KA, Pirovano W, Krab K, Heringa J (2007) Sequence harmony: detecting functional specificity from alignments. Nucleic Acids Res $35: 495-498$

Felsenstein J (1985) Confidence limits on phylogenies: an approach using the bootstrap. Evolution 39:783-791

Feng HQ, Wang YF, Li HY, Wang RF, Sun K, Jia LY (2010) Salt stressinduced expression of rice AOX1a is mediated through an accumulation of hydrogen peroxide. Biologia 65:868-873

Florez-Sarasa I, Ostaszewska M, Galle A, Flexas J, Rychter AM, RibasCarbo M (2009) Changes of alternative oxidase activity, capacity and protein content in leaves of Cucumis sativus wild-type and MSC16 mutant grown under different light intensities. Physiol Plant 137:419-426

Giraud E, Ho LHM, Clifton R, Carroll A, Estavillo G, Tan YF et al (2008) The absence of alternative oxidase 1a in Arabidopsis results in acute sensitivity to combined light and drought stress. Plant Physiol 147: 595-610

Giraud E, Van Aken O, Ho LHM, Whelan J (2009) The transcription factor $\mathrm{ABI} 4$ is a regulator of mitochondrial retrograde expression of alternative oxidase 1a. Plant Physiol 150:1286-1296

Havey MJ (1997) Paternal transmission of the cucumber mitochondrial genome. J Hered 88:232-235

Havey MJ, Lilly JW, Bohanec B, Bartoszewski G, Malepszy S (2002) Cucumber: a model angiosperm for mitochondrial transformation? J Appl Genet 43:1-17

Havey MJ, McCreight JD, Rhodes B, Taurick G (1998) Differential transmission of the Cucumis organellar genomes. Theor Appl Genet 97:122-128

Huang S, Li R, Zhang Z, Li L, Gu X et al (2009) The genome of the cucumber, Cucumis sativus L. Nat Genet 41:1275-1281

Ivanova A, Law SR, Narsai R, Duncan O, Lee JH, Zhang B, Van Aken O, Radomiljac JD, van der Merwe M, Yi K, Whelan J (2014) A functional antagonistic relationship between auxin and mitochondrial retrograde signaling regulates alternative oxidase $1 \mathrm{a}$ expression in Arabidopsis. Plant Physiol 165:1233-1254

Juszczuk IM, Flexas J, Szal B, Dąbrowska Z, Ribas-Carbo M, Rychter AM (2007) Effect of mitochondrial genome rearrangement on respiratory activity, photosynthesis, photorespiration and energy status of MSC16 cucumber (Cucumis sativus L.) mutant. Physiol Plant 131: $527-541$

Kanazawa A, Tsutsumi N, Hirai A (1994) Reversible changes in the composition of the population of mtDNAs during dedifferentiation and regeneration in tobacco. Genetics 138:865-870

Karpova OV, Kuzmin EV, Elthon TE, Newton KJ (2002) Differential expression of alternative oxidase genes in maize mitochondrial mutants. Plant Cell 14:3271-3284

Kozik EU, Wehner TC (2008) A single dominant gene $C h$ for chilling resistance in cucumber seedlings. J Amer Soc Hort Sci 133:225-227

Kuzmin EV, Karpova OV, Elthon TE, Newton KJ (2004) Mitochondrial respiratory deficiencies signal up-regulation of genes for heat shock proteins. J Biol Chem 279:20672-20677

Lei T, Feng H, Sun X, Dai QL, Zhang F, Liang HG, Lin HH (2010) The alternative pathway in cucumber seedlings under low temperature stress was enhanced by salicylic acid. Plant Growth Reg 60:35-42

Lilly JW, Bartoszewski G, Malepszy S, Havey MJ (2001) A major deletion in the cucumber mitochonchondrial genome sorts with the MSC phenotype. Curr Genet 40:144-151

Leister D (2012) Retrograde signaling in plants: from simple to complex scenarios. Front Plant Sci 3:135

Ładyżyński M, Burza W, Malepszy S (2002) Relationship between somaclonal variation and type of culture in cucumber. Euphytica 125:349-356

Malepszy S, Burza W, Śmiech M (1996) Characterization of a cucumber (Cucumis sativus L.) somaclonal variant with paternal inheritance. J Appl Genet 37:65-78

Maxwell DP, Wang Y, McIntosh L (1999) The alternative oxidase lowers mitochondrial reactive oxygen production in plant cells. Proc Natl Acad Sci U S A 96:8271-8276

Meyer JDF, Deleu W, Garcia-Mas J, Havey MJ (2008) Construction of a fosmid library of cucumber (Cucumis sativus) and comparative analyses of the eIF4E and eIF(iso)4E regions from cucumber and melon (Cucumis melo). Mol Genet Genomics 279:473-480

McDonald AE (2008) Alternative oxidase: an inter-kingdom perspective on the function and regulation of this broadly distributed 'cyanideresistant' terminal oxidase. Funct Plant Biol 35:535-552

Migocka M, Papierniak A (2011) Identification of suitable reference genes for studying gene expression in cucumber plants subjected to abiotic stress and growth regulators. Mol Breed 28:343-357

Newton KJ, Knudsen C, Gabay-Laughnan S, Laughnan JR (1990) An abnormal growth mutant in maize has a defective mitochondrial cytochrome oxidase gene. Plant Cell 2:107-113 
Ng S, Ivanova A, Duncan O, Law SR, Van Aken O, De Clercq I, Wang Y, Carrie C, Xu L, Kmiec B, Walker H, Van Breusegem F, Whelan J, Giraud E (2013) A membrane-bound NAC transcription factor, ANAC017, mediates mitochondrial retrograde signaling in Arabidopsis. Plant Cell 25:3450-3471

Ng S, De Clercq I, Van Aken O, Law SR, Ivanova A, Willems P, Giraud E, Van Breusegem F, Whelan J (2014) Anterograde and retrograde regulation of nuclear genes encoding mitochondrial proteins during growth, development, and stress. Mol Plant 7:1075-1093

Ordog SH, Higgins VJ, Vanlerberghe GC (2002) Mitochondrial alternative oxidase is not a critical component of plant viral resistance but may play a role in the hypersensitive response. Plant Physiol 129: $1858-1865$

Ramakers C, Ruijter JM, Deprez RH, Moorman AF (2003) Assumptionfree analysis of quantitative real-time PCR data. Neurosci Lett 339: $62-66$

Rhoads DM, McIntosh L (1991) Isolation and characterization of a cDNA clone encoding an alternative oxidase protein of Sauromatum guttatum (Schott). Proc Natl Acad Sci U S A 88: 2122-2126

Rhoads DM, Subbaiah CC (2007) Mitochondrial retrograde regulation in plants. Mitochondrion 7:177-194

Robson CA, Vanleberghe GC (2002) Transgenic plant cells lacking mitochondrial alternative oxidase have increased susceptibility to mitochondria-dependent and -independent pathways of programmed cell death. Plant Physiol 129:1908-1920

Saisho D, Nambara E, Naito S, Tsutsumi N, Hirai A, Nakazono M (1997) Characterization of the gene family for alternative oxidase from Arabidopsis thaliana. Plant Mol Biol 35:585-596

Saitou N, Nei M (1987) The neighbor-joining method: a new method for reconstructing phylogenetic trees. Mol Biol Evol 4:406-425

Shedge V, Arrieta-Montiel M, Christenses AC, Mackenzie SA (2007) Plant mitochondrial recombination surveillance requires unusual RecA and MutS homologs. Plant Cell 19:1251-1264

Shedge V, Davila JI, Arrieta-Montiel MP, Mohammed S, Mackenzie SA (2010) Extensive rearrangement of the Arabidopsis mitochondrial genome elicits cellular conditions for thermotolerance. Plant Physiol 152:1960-1970

Siedow JN, Umbach AL, Moore AL (1995) The active site of the cyanide-resistant oxidase from plant mitochondria contains a binuclear iron center. FEBS Lett 362:10-14

Sosso D, Mbelo S, Vernoud V, Gendrot G, Dedieu A, Chambrier P, Dauzat M, Heurtevin L, Guyon V, Takenaka M, Rogowsky PM (2012) PPR2263 a DYW-subgroup Pentatricopeptide repeat protein, is required for mitochondrial nad5 and cob transcript editing, mitochondrion biogenesis, and maize growth. Plant Cell 24:676-691
Szal B, Łukawska K, Zdolińska I, Rychter AM (2009) Chilling stress and mitochondrial genome rearrangement in the MSC16 cucumber mutant affect the alternative oxidase and antioxidant defense system to a similar extent. Physiol Plant 137:435-445

Tamura K, Stecher G, Peterson D, Filipski A, Kumar S (2013) MEGA6: molecular evolutionary genetics analysis version 6.0. Mol Biol Evol 30:2725-2729

Vandesompele J, De Preter K, Pattyn F, Poppe B, Van Roy N, De Paepe A, Speleman F (2002) Accurate normalization of real-time quantitative RT-PCR data by geometric averaging of multiple internal control genes. Genome Biol 7: RESEARCH0034

Vanlerberghe GC, McIntosh L (1997) Alternative oxidase: from gene to function. Annu Rev Plant Physiol Plant Mol Biol 48:703-734

Vanlerberghe GC (2013) Alternative oxidase: a mitochondrial respiratory pathway to maintain metabolic and signaling homeostasis during abiotic and biotic stress in plants. Int J Mol Sci 14:6805-6847

Wan H, Zhao Z, Qian C, Sui Y, Malik AA, Chen J (2010) Selection of appropriate reference genes for gene expression studies by quantitative real-time polymerase chain reaction in cucumber. Anal Biochem 15:257-261

Whelan J, Millar AH, Day DA (1996) The alternative oxidase is encoded in a multigene family in soybean. Planta 198:197-201

Woodson J, Chory J (2008) Coordination of gene expression between organellar and nuclear genomes. Nat Rev Genet 9:383-395

Wóycicki R, Witkowicz J, Gawroński P, Dąbrowska J, Lomsadze A, Pawełkowicz M, Siedlecka E, Yagi K, Pląder W, Seroczyńska A, Śmiech M, Gutman W, Niemirowicz-Szczytt K, Bartoszewski G, Tagashira N, Hoshi Y, Borodovsky M, Karpiński S, Malepszy S, Przybecki Z (2011) The genome sequence of the North-European cucumber (Cucumis sativus L.) unravels evolutionary adaptation mechanisms in plants. PLoS One 6, e22728

Yang L, Koo DH, Li Y, Zhang X, Luan F, Havey MJ, Jiang J, Weng Y (2012) Chromosome rearrangements during domestication of cucumber as revealed from high-density genetic mapping and draft genome assembly. Plant J 71:895-906

Zarkovic J, Anderson SL, Rhoads DM (2005) A reporter gene system used to study developmental expression of alternative oxidase and isolate mitochondrial retrograde regulation mutants in Arabidopsis. Plant Mol Biol 57:871-888

Zhang L, Oh Y, Li H, Baldwin IT, Galis I (2012) Alternative oxidase in resistance to biotic stresses: Nicotiana attenuata AOX contributes to resistance to a pathogen and a piercing-sucking insect but not Manduca sexta larvae. Plant Physiol 160:1453-1467

Zuckerkandl E, Pauling L (1965) Evolutionary divergence and convergence in proteins. In: Bryson V, Vogel HJ (eds) Evolving genes and proteins. Academic Press, New York, pp 97-166 